\title{
THE ORIGIN AND FATE OF VOLATILE TRACE COMPONENTS IN MUNICIPAL SOLID WASTE LANDFILLS
}

\author{
Anna Deipser and Rainer Stegmann \\ Technische Universität Hamburg-Harburg, Arbeitsbereich Abfallwirtschaft und Stadttechnik, \\ Harburger Schloßstr. 37, 21079 Hamburg, Germany
}

(Received 10 June 1992, accepted in revised form 24 August 1993)

\begin{abstract}
The content of readily volatile halogenated hydrocarbons (chlorinated and chlorinated, fluorinated hydrocarbons (VCCs/CFCs) ) and the BTEX aromatic substances (benzene, toluene, ethylbenzene and xylene) in municipal solid waste (MSW) was determined by two different methods. Moreover, the emission potential of these substances via the gas and leachate phase was investigated during the different biological degradation phases in the landfill. Trichlorofluoromethane (R11), dichlorodifluoromethane (R12) and dichloromethane (R30) were the dominating halogenated trace substances detected in the MSW. In the acid phase, with some VCCs' CFCs the emittance may take place up to $30 \%$ via the water phase. Hexane, benzene, and toluene could be detected in all tests. Toluene often occurred in relatively high concentrations in MSW. It could be shown that R 11 degraded into dichlorofluoromethane (R21).
\end{abstract}

Key Words-VCCs, CFCs, BTEX, municipal solid waste, emission potential, anaerobic degradation, degradation of R11, leachate, gas phase.

\section{Introduction}

Readily volatile chlorinated hydrocarbons (VCCs), chlorinated, fluorinated hydrocarbons (CFCs) and non-halogenated hydrocarbons enter the landfills with the municipal solid waste (MSW). As a consequence, considerable concentrations of these components are to be found in landfill gas and leachate. When the landfill gas is utilized in internal combustion engines, VCCs and CFCs may be converted into hydrogen fluoride and hydrogen chloride which may cause severe corrosion damage to the engines (Dernbach 1984). Therefore, costly adsorption units, which reduce the content of these substances in the landfill gas to a nominal value and/or sophisticated operation techniques, may become necessary. The compounds containing halogens are also undesirable in incineration plants since they contribute to the increase of hydrogen chloride and hydrogen fluoride mass loadings in the flue gas.

Due to the destructive effect which especially the CFCs have on ozone (Anonymous 1987) and the toxicity of some components it is important to evaluate the emission potential of MSW landfills in view of future measures in landfill technique. The readily volatile aromatic substances (benzene, toluene, ethyl benzene and m,p,o-xylene) often occur at relatively high concentrations in the landfill gas. They are constituents of petroleum and can therefore reach the MSW or MSW-like trade waste via motor oils, fuels, solvents, and wood preservatives. Benzene is definitely carcinogenic, while toluene, ethyl benzene and the xylenes are classified as being less toxic (Koch 1989). Hexane, the only readily volatile alkane which is regarded as not being damaging to health, occurs in MSW but is normally not considered in landfill gas analyses. 


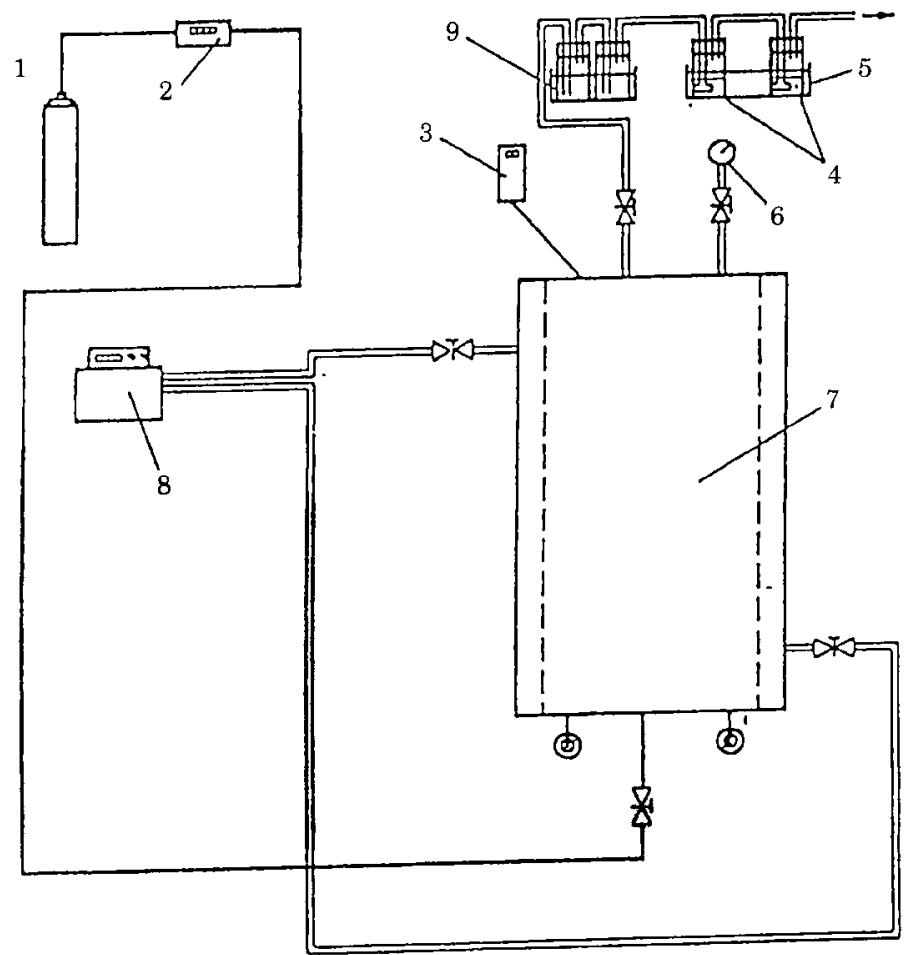

Fig. 1. Scheme of the experimental stripping plant. 1, nitrogen bottle; 2 , gas meter; 3 , temperature gauge; 4 , washing bottle with sorbent; 5 , cooling water; 6 , manometer; 7 , aluminium vessel; 8 , heater; 9 , condensation trap.

A research project carried out at the Technical University of Hamburg-Harburg recently investigated the total content of readily volatile trace organics in the MSW.

\section{Experimental methodology}

The experiments were carried out with fresh (1 week old) MSW samples from Hamburg, Germany. The samples were taken at an incineration plant from MSW collected by dustcarts. Trade waste and industrial waste were not used. The sampled waste material was sieved to a diameter of $100 \mathrm{~mm}$. A sample volume of approximately 801 (approximately $10 \mathrm{~kg}$ ) was chosen in an attempt to get a representative sample. The samples were installed in the anaerobic digesters immediately upon sampling so that as little as possible of the readily volatile components could escape. To determine the total content of VCCs, CFCs and the BTEX aromatic substances two different methods were chosen:

\subsection{Stripping tests in an experimental plant at different temperatures}

In the experimental stripping plant outlined in Fig. 1, fresh MSW samples of approximately $10 \mathrm{~kg}$ each were examined. After the samples had been installed the tightness of the container was examined by a pressure test at 5 bar. 
TABLE 1

The parameters of headspace-gas chromatographic analysis

\begin{tabular}{ll}
\hline GC & $:$ Packard Instruments gaschromathograph GC436 \\
integrator & $:$ Packard Control and Integration System (PCI) connected to a \\
& printer \\
column & $\begin{array}{l}: 50 \mathrm{~m} \times 0.53 \mathrm{~mm} \text { fused Silica WCOT capillary column with the } \\
\text { chemical bonded stationary phase CP-SIL } 5 \mathrm{CB} \text { and } 5 \mu \mathrm{m} \text { film } \\
\text { thickness }\end{array}$ \\
detector & $:$ FID \& ECD \\
carrier gas & $:$ nitrogen \\
temperature programme & $: 4 \mathrm{~min}$ at $32^{\circ} \mathrm{C}, 10^{\circ} \mathrm{C} / \mathrm{min} \rightarrow 82^{\circ} \mathrm{C}, 15^{\circ} \mathrm{C} / \mathrm{min} \rightarrow 187^{\circ} \mathrm{C}$ \\
headspace apparatus & $:$ Dani, HSS 3950 \\
thermostation time & $: 60 \mathrm{~min}$ \\
sample loop & $: 1 \mathrm{ml}$ \\
standard & $:$ external \\
\hline
\end{tabular}

For several hours the sample was heated and stripped in succession at three temperature levels $\left(30,45\right.$ and $\left.75^{\circ} \mathrm{C}\right)$. Nitrogen was used as carrier gas. The sorption of VCCs, CFCs and BTEX took place in two wash bottles filled with $150 \mathrm{ml}$ benzyl alcohol which was cooled down to $0^{\circ} \mathrm{C}$. The solvent and the condensation water, which was collected separately, were analysed in a head-space gas chromatograph (Table 1). For this purpose $5 \mathrm{ml}$ sample volumes were each gas-tightly sealed in small head-space glasses.

The detection limit for the individual substances is $1 \mu \mathrm{g} 1^{-1}$. Part of the MSW sample was installed in a laboratory anaerobic digester. This enabled the comparison to be made between the results from the stripping tests at different temperatures and long-term experiments in the laboratory.

\subsection{Experiments in laboratory anaerobic digesters}

In the 1101 test containers outlined in Fig. 2 approximately $15 \mathrm{~kg}$ (dry matter) of fresh MSW samples was mixed with approximately $5 \mathrm{~kg}$ (dry matter) of compost which was 24 months old.

The compost was used to accelerate the anaerobic degradation processes in the MSW (Stegmann 1981, Spendlin 1991). The moisture content of the MSW/compost mixture was between $50-70 \%$ and the temperature was kept at $30^{\circ} \mathrm{C}$. Under these conditions which are favourable to anaerobic degradation processes, in some of the containers the methane phase could be reached within one year. Analyses of the gas and leachate phase for the substances presented in Table 1 enabled one to make an assessment of the distribution of these readily volatile components in the gas and leachate.

The detection limit of the stated trace organics was between $0.005 \mathrm{and} 2 \mathrm{mg} \mathrm{m}^{-3}$ in the gas phase (Table 2) and $1 \mu \mathrm{g} \mathrm{l}^{-1}$ in the water phase (Table 1). The detection limit for vinyl chloride and the hydrocarbons was between $0.1-0.01 \mathrm{mg} \mathrm{l}^{-1}$.

In order to determine the total content of the volatile organics in the sampling material that had been placed in the anaerobic digesters, part of the material was stripped in the unit described above (see Fig. 1). From the calculation of the mass loadings in the gas and leachate phase over a period of one year, the quantity of the volatile trace organics was determined. This calculation is based on weekly analyses of the gas and leachate. In this way the residual content of the volatile organics in the MSW/compost mixture could be determined. 


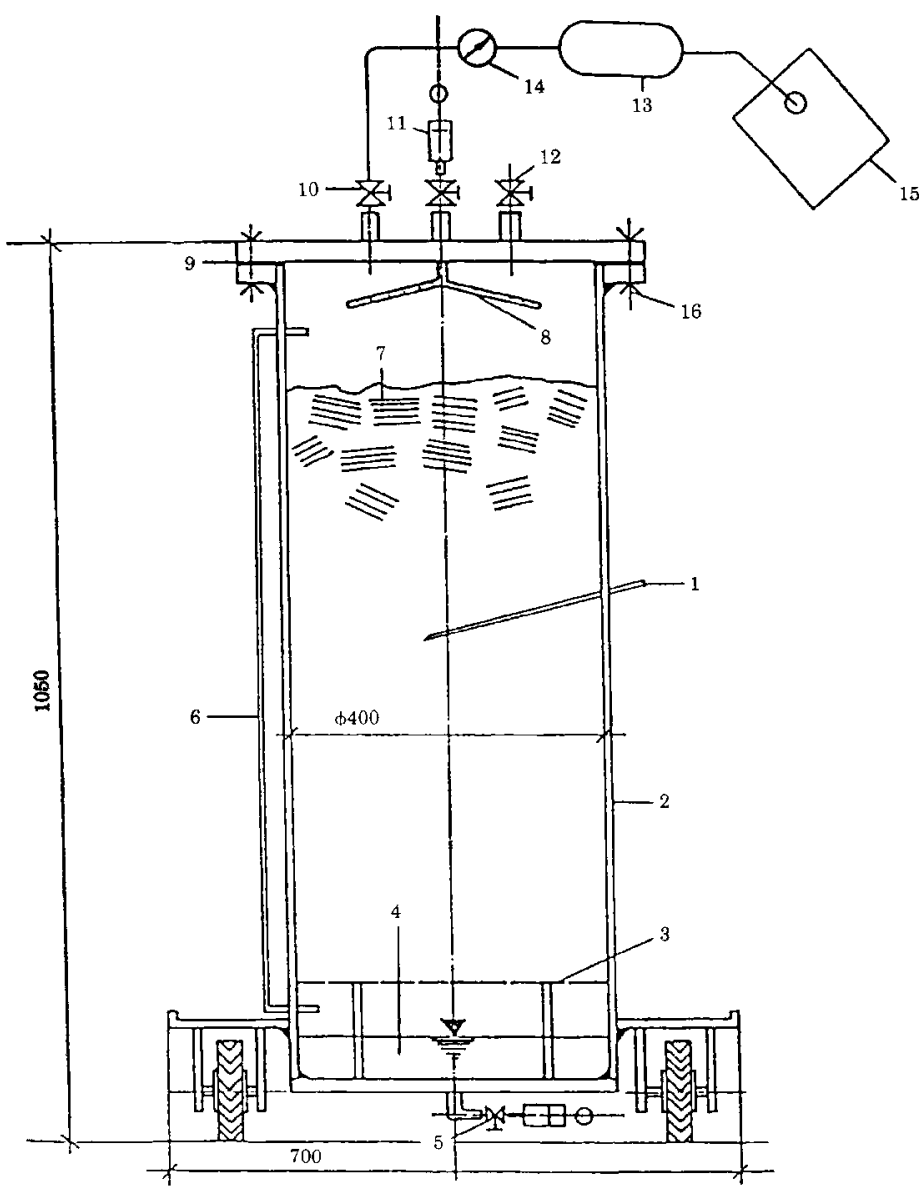

Fig. 2. Scheme of the 110-litre anaerobic digester (Stegmann 1981). 1, sensor of temperature; 2, high-grade steel; 3, perforated metal; 4, leachate; 5, effluent; 6, pressure exchange; 7, municipal solid waste sample; 8 , water or leachate distribution; 9 , sealing ring; 10, gas collection; 11 , valve for water or leaching addition; 12 , reserve valve; 13 , gas collection tube; 14, measuring device for gas production; 15 , gas collection bag; 16, bolts.

TABLE 2

The parameters of gas chromatographic analysis

GC

integrator

column

detector

carrier gas

temperature programme

standard
: Packard Instruments gaschromathograph GC439

Shimadzu C-R2A

$50 \mathrm{~m} \times 0.53 \mathrm{~mm}$ fused Silica WCOT capillary column with the stationary phase $\mathrm{Al}_{2} \mathrm{O}_{3} / \mathrm{KCl}$ and $5 \mu \mathrm{m}$ film thickness

\section{FID \& ECD}

nitrogen

: $1 \mathrm{~min}$ at $50^{\circ} \mathrm{C}, 4^{\circ} \mathrm{C} \mathrm{min}^{-1} \rightarrow 190^{\circ} \mathrm{C}$

external 


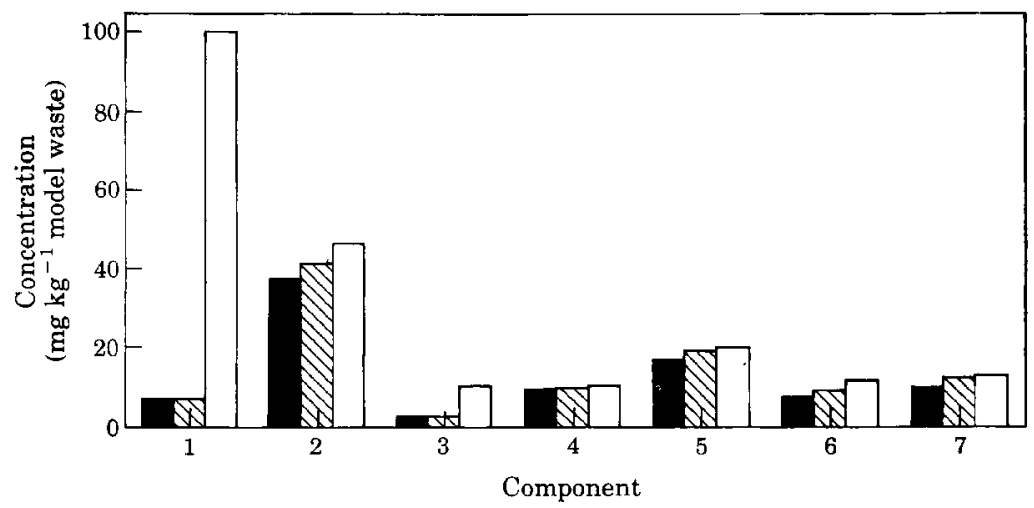

Fig. 3. Some retrieval rates of the measured substances. ( $\square$ ), 1st stripping test; (\$), 2nd stripping test; ( $\square$ ) 100\%. 1, Trichlorofluoromethane (R11); 2, Dichloromethane (R30); 3, cis-1,2-Dichloroethene; 4, Trichloromethane (R20); 5, 1,1,1-Trichloroethane; 6, Trichloroethene; 7, Tetrachloroethene.

TABLE 3

Concentrations of halogenated trace substances in six MSW

Component

Concentration

(mg kg-1 $\mathrm{TS}$ waste)

Trichlorofluoromethane (R11)

nd -10.79

Dichlorodifluoromethane (R12)

$0.01-0.22$

Dichlorofluoromethane (R21)

nd -0.89

Chlorodifluoromethane (R22)

$0.01-0.24$

1,1,2-Trichlorotrifluoroethane (R113)

nd -0.01

Dichloromethane

$0.01-2.68$

Trichloromethane nd- 0.07

1,1,1-Trichloroethane

Monochloroethene (Vinylchloride)

$0.01-3.65$

nd- 0.4

cis-1,2-Dichloroethene

nd -4.99

Trichloroethene

nd -0.59

Tetrachloroethene

nd-1.41

nd: not detectable.

\section{Total content of VCCs/CFCs and BTEX in municipal solid waste}

It proved to be extremely difficult to determine the total content of VCCs and CFCs during the thermal stripping. The absorption of VCCs/CFCs to the material "MSW" seems to be high. Therefore, even after several hours of operation the total amount of the substances could not be measured. The determination of the retrieval rate of the measured substances varied widely. As expected, the retrieval rate for components with higher boiling-points was higher than that of the readily volatile substances as trichlorofluoromethane (R11) (Fig. 3).

In Tables 3 and 4 the concentrations measured are shown. The fluorine and chlorine concentrations were between $0.153-7.16 \mathrm{mg}$ org. $\mathrm{Cl} \mathrm{kg} \mathrm{MSW}^{-1}$ and $0.004-3.87 \mathrm{mg}$ org. 
TABLE 4

Hexane and BTEX-aromatic substances in six MSW samples

\begin{tabular}{lc}
\hline Component & $\begin{array}{c}\text { Concentration } \\
\text { (mg kg }\end{array}$ \\
\hline Hexane & TS waste) \\
Benzene & $0.02-0.22$ \\
Toluene & $0.02-0.68$ \\
Ethylbenzene & $0.1-2.08$ \\
o-Xylene & nd-0.39 \\
m,p-Xylene & nd-1.21 \\
\hline
\end{tabular}

nd: not detectable.

$\mathrm{F} \mathrm{kg} \mathrm{MSW}^{-1}$. The concentrations were clearly below those presented elsewhere (Deipser et al. 1991).

Sporadic measurements of the gas stream after the washbottles showed concentrations near the detection limit. In comparison to the quantity of adsorbed material in the washbottles, this mass loading was negligible. The thermal stripping tests were developed with the aim of determining the readily volatile contaminants in waste and waste fractions in a short time. However, due to the adsorption/desorption behaviour of one group of substances and the extreme mobility of the readily volatile substances, especially in the lower concentration ranges, only an insufficient reproducibility could be obtained.

\section{VCC/CFC concentrations in the test containers in the gas phase}

The VCC/CFC concentrations in the gas phase varied greatly in the individual anaerobic digesters. Concentrations in the range of $50-20,000 \mathrm{mg}$ of organic $\mathrm{Clm}^{-3}$ could be measured. The highest concentrations of trace organics were measured during the acid phase. This is due to the fact that gas production is very low during this phase and only little dilution occurs; in addition during the acid stage the highest VCC/CFC concentrations are in the MSW. Once the methane phase starts, gas production also occurs (Stegmann) 1981); the readily volatile substances are desorbed but diluted by the biogas. Since the amount of trace organics is limited, the concentrations decrease with time down below the detection limit. In the 15 different MSW samples great variations in the concentration of the individual substances were found. As these substances are contained in specific MSW components such as spray cans, paints, lacquers, etc. (Deipser 1989) it can be assumed that $\mathrm{VCC} / \mathrm{CFC}$ concentrations in areas around these components are significantly higher.

Trichlorofluoromethane (R11), dichlorodifluoromethane (R12) and dichloromethane (R30) were the dominating halogenated trace substances detected in the MSW. However, also 1,1,1-trichloroethane, cis-1,2-dichloroethene were detected in relatively high concentrations. As R11 and R12 are used in spray cans, in plastic foam and as refrigerants in refrigerators/freezers and the above-mentioned VCCs are used in solvents, paints and lacquers, the occurrence of the substances in the MSW was to be expected (Deipser 1989). In Table 5 the maximum concentrations of the substances that occurred most frequently in the gas phase are listed. 
TABLE 5

Maximum concentrations of halogenated trace substances in the gas and leachate from six laboratory anaerobic digesters filled with MSW

\begin{tabular}{lcc}
\hline Component & $\begin{array}{c}\text { Gas } \\
\text { concentration } \\
\left(\mathrm{mg} \mathrm{Nm}^{-3}\right)\end{array}$ & $\begin{array}{c}\text { Leachate } \\
\text { concentration } \\
\left(\mathrm{mg} \mathrm{l}^{-1}\right)\end{array}$ \\
\hline Trichlorofluoromethane (R11) & 100 & 0.8 \\
Dichlorodifluoromethane (R12) & 3200 & 2.9 \\
Dichlorofluoromethane (R21) & 13 & 0.6 \\
Chlorodifluoromethane (R22) & 385 & 0.9 \\
1,1,2-Trichlorotrifluoroethane (R113) & 34 & 1.9 \\
Dichloromethane & 30 & 0.4 \\
1,1,1-Trichloroethane & 174 & 26.5 \\
Monochloroethene (Vinylchloride) & 31 & 2.5 \\
cis-1,2-Dichloroethene & 77 & 5.3 \\
Trichloroethene & 30 & 0.4 \\
Tetrachloroethene & 63 & 0.7 \\
\hline
\end{tabular}

Vinyl chloride was detected in a laboratory scale anaerobic digester. It is assumed that it is a decomposition product of dichloroethene or of tri- or tetrachloroethene (Vogel \& McCarty 1985).

\subsection{VCCs/CFCs in the anaerobic digesters in the water phase}

Leachate analyses of the anaerobic digesters show that only during the acid phase, i.e. at a $\mathrm{pH}$ value of about 5 , are measurable concentrations of the above-mentioned substances found. With an increasing $\mathrm{pH}$ value, the concentrations of all VCCs/CFCs decrease with time below detection limits. The maximum concentrations of the substances most frequently found in the leachate are shown in Table 5.

The maximum concentration of organic $\mathrm{Cl}$ in the leachate was $21.2 \mathrm{mg} \mathrm{Cll}^{-1}$ for about one third of the total testing period of 322 days.

The substances detected in the leachate are qualitatively and quantitatively correlated to those measured in the gas phase. However, due to the different distribution coefficients gas/water of the different VCCs/CFCs substance-specific concentration variations in the leachate were detected. Thus a high concentration of a substance in the leachate cannot necessarily be predicted from high concentrations in the gas phase.

\subsection{Hexane and BTEX concentrations in the anaerobic digesters in the gas phase}

Hexane, benzene, and toluene could be detected in all test containers. The maximum concentrations are shown in Table 6.

Ethyl benzene and xylenes occurred sporadically in relatively high concentrations, which cannot be explained. A reason might be the relatively high boiling-point and the specific adsorption behaviour of these substances. That may result in higher emission rates via the gas phase during high gas production rates.

\subsection{Hexane and BTEX concentrations in the anaerobic digesters in the water phase}

Hexane and BTEX aromatic substances were found in the leachate during the acid phase at relatively constant concentrations. The concentrations of these substances also 
TABLE 6

Maximum hexane and BTEX concentrations in the gas phase and leachate from six laboratory anaerobic digesters filled with MSW

\begin{tabular}{lcc}
\hline Component & $\begin{array}{c}\text { Gas } \\
\text { concentration } \\
\left(\mathrm{mg} \mathrm{Nm}^{-3}\right)\end{array}$ & $\begin{array}{c}\text { Leachate } \\
\text { concentration } \\
\left(\mathrm{mg} \mathrm{l}^{-1}\right)\end{array}$ \\
\hline Hexane & 4.8 & 0.07 \\
Benzene & 8.3 & 0.47 \\
Toluene & 16.0 & 0.09 \\
Ethylbenzene & 11.4 & 0.09 \\
o-Xylene & 6.5 & 0.05 \\
m,p-Xylene & 23.9 & 0.11 \\
\hline
\end{tabular}

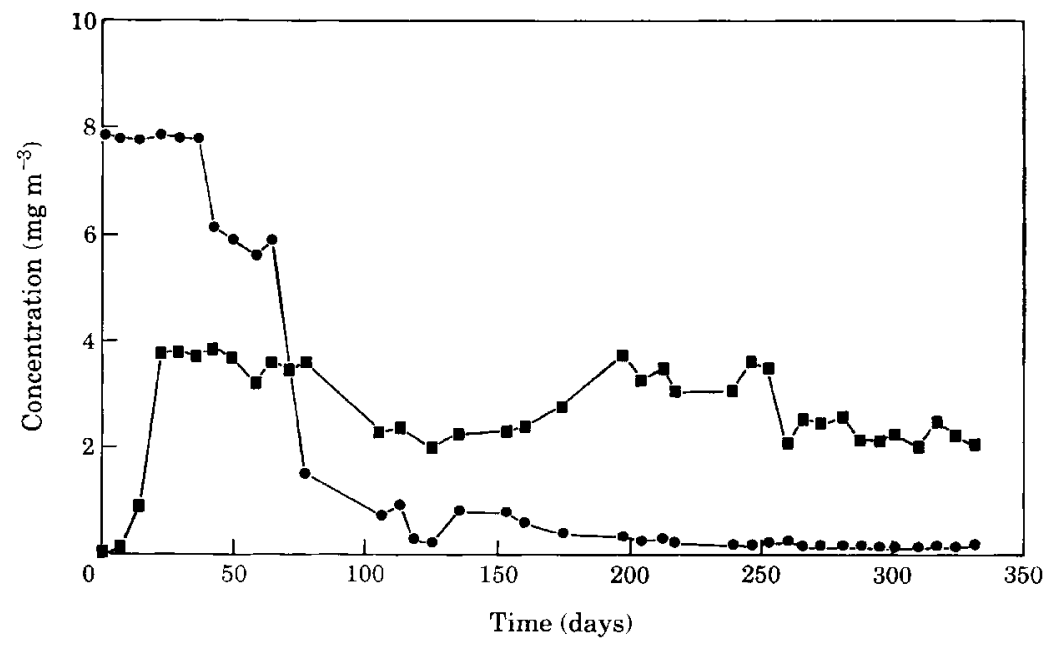

Fig. 4. Degradation of R11 into R21 in the acid phase in gas from laboratory anaerobic digesters filled with MSW. ( ๑), R11; ( $\mathbf{\square})$, R21.

decreased down below the detection limit after the methane phase had started (connected with an increase of the $\mathrm{pH}$ value). The maximum concentrations which were detected are presented in Table 6 .

\section{Degradation of $R 11$ and $R 12$ under anaerobic landfill milieu conditions}

Dichlorofluoromethane (R21) was measured in the gas phase of the laboratory digesters as well as in gas from actual landfills, but there are no waste components known that contain R21. A reductive dehalogenation of the CFCs is theoretically possible, where at first R11 is degraded into R21 and R12 into E22. A further degradation of R21 into chlorofluoromethane (R31) and fluoromethane (R41) could be possible. The investigations carried out have shown that $R 11$ is degraded into $R 21$ in the acid phase as well as in the methane phase (see Figs 4 and 5). Since in the gas phase of the anaerobic test digesters only very low concentrations of R11 could be detected, $5 \mathrm{mg} \mathrm{kg}_{\mathrm{dwt} \text { waste }}^{-1}$ of R11 


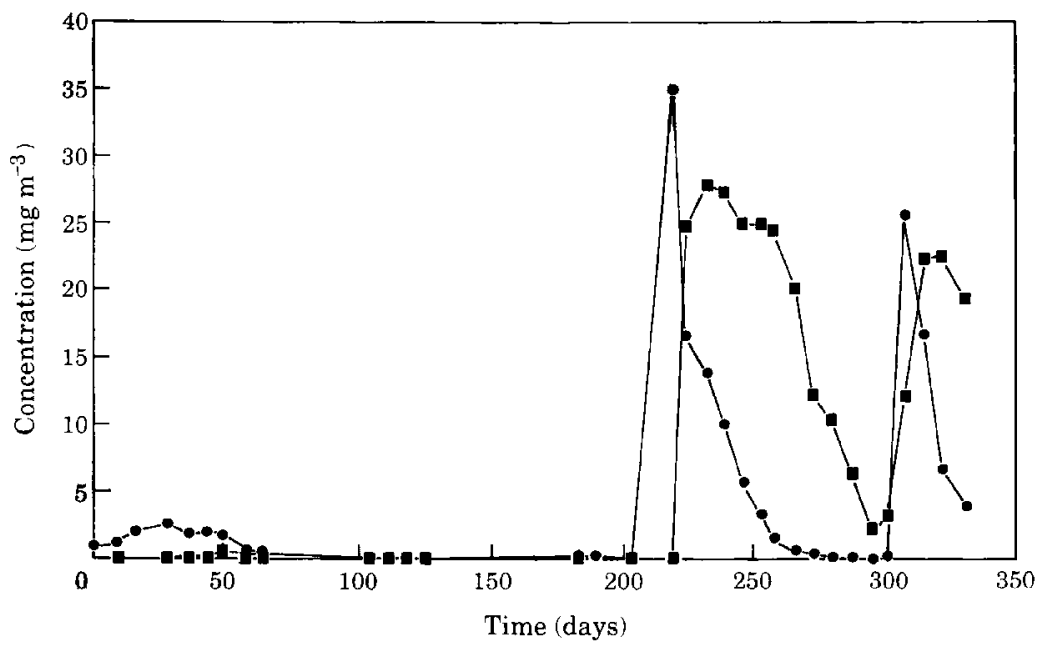

Fig. 5. Degradation of R11 into R21 in the methane phase in laboratory anaerobic digesters filled with MSW. (O), R11; ( $)$, R21.

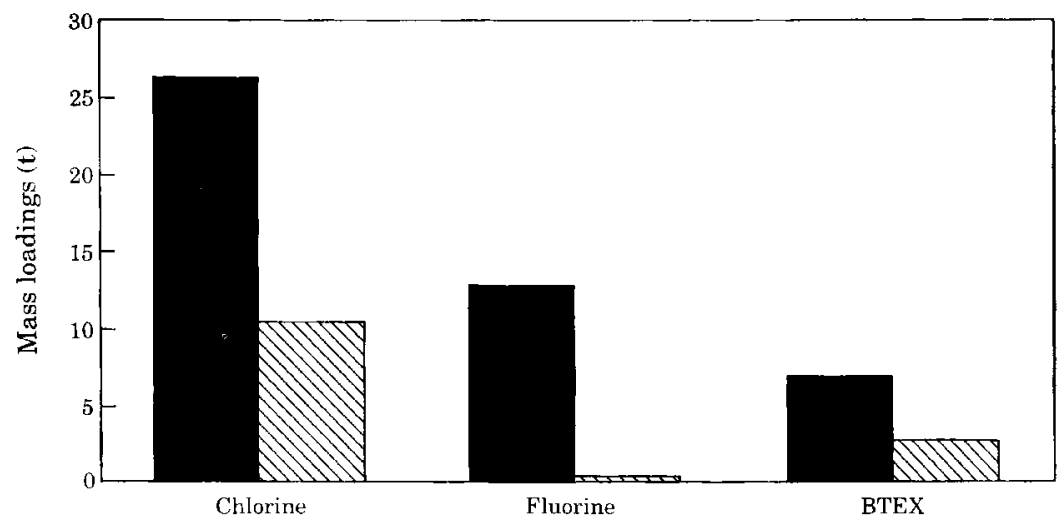

Fig. 6. Organic chlorine, fluorine and BTEX mass loadings from 13.5 million $t$ of MSW annually landfilled in the former FRG. ( $\mathbf{\square})$, gas phase; $\mathbb{\mathbb { N }}$ ), water phase.

was injected into the MSW (day 220). After a few days, the degradation product R21 could be detected in the gas phase, where in the beginning increasing concentrations were measured. The fluctuation in the degradation of R1l is a subject of further investigations.

These are the first results that show that degradation takes place; further investigations are necessary in order to be able to interpret the different curves of contractions measured in the two different phases. 


\section{Practical consequences of the investigations}

The investigations showed that in the acid phase $\approx 28 \%$ of the organic chlorine content, $\approx 3 \%$ of the organic fluorine content and $\approx 29 \%$ of the BTEX content were emitted via the leachate. With the start of the methane phase the content of trace organics in the leachate was considerably reduced. This means that 13.5 million $t$ MSW (the annual amount of MSW that was landfilled in the former Federal Republic of Germany in 1990) contain a total of $\approx 36.7 \mathrm{t}$ organic chlorine, $\approx 13.2 \mathrm{t}$ organic fluorine and $\approx 10 \mathrm{t}$ aromatic substances that, according to these investigations, could possibly be released. During the acid phase $\approx 10.4 \mathrm{t}$ chlorine, $\approx 0.4 \mathrm{t}$ fluorine and $\approx 2.8 \mathrm{t}$ BTEX aromatic substances could escape with the leachate (Fig. 6).

To achieve lower mass loadings of readily volatile contaminants in the leachate one should aim at reaching the methane phase in the landfill at the earliest possible time (Stegmann 1983). To reduce the readily volatile contaminants in the MSW the entry of products containing VCCs/CFCs such as spray cans, PVR-foam, paints, lacquers and solvents should be avoided. This could be achieved by separate collection. The most efficient alternative in this regard would be to stop the production of products which can be effectively substituted.

\section{Summary and discussion of the results}

The investigation of MSW samples for the content of volatile trace components in laboratory-scale tests is described using two different methods: simulation of the biological processes in landfill and stripping at different temperatures. Variations of the results occurred which were due to the small sampling volume. Problematic are the different adsorption-desorption characteristics for the VCCs/CFCs, which makes the assessment of the residual content in the samples difficult. It happened also that high concentrations of the VCCs/CFCs were suddenly to be found in the MSW samples. This was the case when, for example, spray cans were damaged or corroded so that VCCs/ CFCs were released.

During the simulation of the biological processes in landfills in the acid phase, some VCCs/CFCs were emitted up to $30 \%$ via the water phase. Under these conditions gas production is very low. In the methane phase, significantly lower concentrations of trace organics leave the landfill via the water phase, which is possibly related to the increase of the $\mathrm{pH}$ value in the leachate and to higher gas production rates (stripping effect). Consequently, a reduction of the VCC/CFC-contents in the leachate could be achieved by an early start of the methane phase.

Using the thermal stripping test the determination of the total content of the readily volatile trace components was not satisfactory again due to the good absorption/ adsorption characteristics of the material "municipal solid waste" within the short investigation period (a few days). Normally the total content measured with this method was below that measured in the samples from the laboratory-scale anaerobic digesters. Therefore more exact results are gained when the total content of trace organics is determined via the emissions during the gas and leachate phase of a laboratory anaerobic digester, provided that there are no waste components which release VCCs/ CFCs in a concentrated way (e.g. spray cans). But it is necessary that almost the total gas production is analysed, since in the methane phase the trace organics are emitted almost completely via the gas phase. In most of the laboratory-scale digesters this can be achieved after a period of fermentation of about one year. The measured concentrations 
of the organic trace components emitted from "normal" MSW are so high that, due to the problems connected with the occurrence of VCCs/CFCs in the leachate and the landfill gas (high costs of leachate treatment, corrosion inside gas engines), those waste components causing the above-mentioned problems should not get into the landfill. Furthermore the use of $\mathrm{VCCs} / \mathrm{CFCs}$ should be reconsidered on principle.

Vinyl chloride occurred in a MSW sample during laboratory testing. It is assumed that it is a degradation product of dichloroethene or tri- or tetrachloroethene. In addition initial results show that $\mathrm{R} 11$ is degraded into $\mathrm{R} 21$. Investigations are being carried out at the Technical University of Hamburg-Harburg within a current research project sponsored by the Deutsche Forschungsgemeinschaft to describe this degradation process in more detail.

\section{References}

Anonymous (1987) Anthropogene Beeinflussung der Ozonschicht (Anthropogenic influences on the ozone layer). 6th Dechema Expert Conference on Environmental Protection, December 1987.

Dernbach, H. (1984) Korrosionsprobleme beim Betrieb der Blockheizkraftwerke auf der Deponie Braunschweig, Dokumentation einer Fachtagung (Corrosion problems during the operation of unit heating power stations at the landfill of Braunschweig, proceedings of an expert conference). Hamburg, Germany, BMFT-Berichte, 1985.

Deipser, A. (1989) Quellen leichtflüchtiger halogenierter Kohlenwasserstoffe im Hausmüll und hausmüllähnlichem Gewerbemüll (Sources of readily volatile halogenated hydrocarbons in municipal solid waste and similar trade waste). Dissertation submitted for diploma, not published.

Deipser, A., Poller, T. \& Stegmann, R. (1991) Untersuchungen zum Verhalten von ausgewählten organischen Schadstoffen unter kontrollierten Deponiemilieubedingungen in Laborlysimetern (Investigations on the behaviour of selected organic contaminants under controlled landfill milieu conditions in laboratory lysimeters), final report of a research project, funded by the "Deutsche Forschungsgemeinschaft (DFG)", not published.

Koch, R. (1989) Umweltchemikalien (Chemicals hazardous to the environment). VCH Verlagsgesellschaft, Germany.

Spendlin, H.-H. (1991) Untersuchungen zur frühzeitigen Initiierung der Methanbildung bei festen Abfallstoffen (Investigations on the carly initiation of the methane phase with solid waste materials). Hamburger Berichte 4. Economica Verlag, Bonn, Germany.

Stegmann, R. (1981) Beschreibung eines Verfahrens zur Untersuchung anaerober Umsetzungsprozesse von festen Abfallstoffen im Labormaßstab (Description of a procedure to investigate anaerobic degradation processes with solid waste materials in laboratory scale). Müll und Abfall 2.

Stegmann, R. (1983) New aspects on enhancing biological processes in sanitary landfill. Waste Management \& Research 1, 201-211.

Vogel, T. M. \& McCarty, P. L. (1985) Biotransformation of tetrachlorethylene to trichlorethylene, dichlorethylene, vinyl chloride, and carbon dioxide under methanogenic conditions. Applied and Environmental Microbiology, May 1985. 